\title{
Pengolahan Limbah Industri Elektroplating Dengan Proses Koagulasi Flokulasi
}

\author{
Nurhasni $^{1}$, Zainus Salimin ${ }^{2}$, Ita Nurifitriyani ${ }^{3}$ \\ ${ }^{1,3}$ Program Studi Kimia Fakultas Sains dan Teknologi UIN Syarif Hidayatullah Jakarta, \\ Jalan Ir. H. Juanda No. 95, Ciputat 15412 Indonesia. Telp. (62-21) 7493606 \\ ${ }^{2}$ Pusat Teknologi Pengolahan Limbah Radioaktif BATAN, Kawasan Puspitek Serpong, \\ Tangerang 15314, Telp (021) 7563142 \\ Email : hasni1806@gmail.com
}

\begin{abstract}
Abstrak
Penelitian pengolahan limbah industri elektroplating dengan proses koagulasi flokulasi telah dilakukan. Penelitian bertujuan untuk mengetahui proses pengolahan dengan koagulan $\mathrm{FeCl}_{3}$ dalam menurunkan kandungan logam berat pada limbah elektroplating, rasio massa koagulan dan limbah, $\mathrm{pH}$ optimum dan massa $\mathrm{KI}$ optimum untuk mereduksi $\mathrm{Cr}^{6+}$ menjadi $\mathrm{Cr}^{3+}$. Hasil jar test diperoleh $\mathrm{pH}$ optimum yaitu $\mathrm{pH}$ 8. Massa optimum $\mathrm{KI}$ untuk mereduksi $\mathrm{Cr}^{6+}$ menjadi $\mathrm{Cr}^{3+}$ yaitu $0,3 \mathrm{~g}$. Penurunan kadar krom dengan proses reduksi sebesar $83,36 \mathrm{mg} / \mathrm{L}$ atau persentase penyisihan sebesar 95,02\% sedangkan penurunan optimal kadar Cr tanpa reduksi yaitu sebesar 87,32 mg/L atau $99,51 \%$. Penggunaan koagulan $\mathrm{FeCl}_{3}$ pada pengolahan limbah industri elektroplating dapat menurunkan kadar logam berat $\mathrm{Fe}, \mathrm{Cr}, \mathrm{Zn}, \mathrm{Cu}, \mathrm{Ni}$ dan $\mathrm{Mn}$ sampai pada nilai baku mutunya.
\end{abstract}

Kata Kunci : Koagulasi flokulasi, Ferri klorida, Limbah simulasi elektroplating, Jar test, SSA.

\begin{abstract}
Study on the water treatment of electroplating industrial waste by coagulation flocculation has been carried out. Determine the treatment process with coagulant $\mathrm{FeCl}_{3}$ in reducing the heavy metal content in the electroplating waste, coagulant and waste mass ratio, $\mathrm{pH}$ optimum and optimum mass of $\mathrm{KI}$ to reduce $\mathrm{Cr}^{6+}$ to $\mathrm{Cr}^{3+}$. Jar test results available optimum $\mathrm{pH}$ 8. The optimum mass of $\mathrm{KI}$ to reduce the $\mathrm{Cr}^{6+}$ to $\mathrm{Cr}^{3+}$ is $0.3 \mathrm{~g}$. Decrease in optimal levels of $\mathrm{Cr}$ in the reduction that is equal to $83,36 \mathrm{mg} / \mathrm{L}$ or $95,02 \%$ while the decrease in optimal levels of $\mathrm{Cr}$ with no reduction process is equal to $87,32 \mathrm{mg} / \mathrm{L}$ or $99,51 \%$. The use of coagulant $\mathrm{FeCl}_{3}$ the electroplating industry wastewater treatment can reduce levels of heavy metals $\mathrm{Fe}, \mathrm{Cr}, \mathrm{Zn}, \mathrm{Cu}, \mathrm{Ni}$ and $\mathrm{Mn}$ to the quality of raw values.
\end{abstract}

Keywords: Coagulation flocculation, Ferric chloride, simulated electroplating waste, Jar test, SSA.

\section{PENDAhULUAN}

Meningkatnya kebutuhan akan produk yang menggunakan proses elektroplating mendorong berkembangnya industri elektroplating yang berada di Indonesia. Perkembangan industri yang semakin pesat tersebut selain memberikan manfaat, juga menimbulkan dampak negatif dari limbah yang dihasilkan. Limbah dari proses elektroplating merupakan limbah logam berat yang termasuk dalam limbah B3 (Bahan Beracun Berbahaya) (Purwanto, 2005).

Beberapa unsur logam yang terdapat dalam limbah cair elektroplating antara lain besi, krom, seng, nikel, mangan, dan tembaga. 
Kuantitas limbah yang dihasilkan dalam proses elektroplating tidak terlampau besar, tetapi tingkat toksisitasnya sangat berbahaya, terutama krom, nikel dan seng (Roekmijati, 2002). Karakteristik dan tingkat toksisitas dari air limbah elektroplating bervariasi tergantung dari kondisi operasi dan proses pelapisan serta cara pembilasan yang dilakukan (Palar, 1994). Pembuangan langsung limbah dari proses elektroplating tanpa pengolahan terlebih dahulu ke lingkungan dapat menyebabkan pencemaran lingkungan. Cemaran tersebut dapat mencemari mikroorganisme dan lingkungannya baik dalam bentuk larutan, koloid, maupun bentuk partikel lainnya. Mengingat penting dan besarnya dampak yang ditimbulkan bagi lingkungan maka diperlukan suatu pengolahan terlebih dahulu sebelum efluent limbah tersebut dibuang ke lingkungan.

Beberapa proses penghilangan kandungan logam berat dapat dilakukan melalui proses pengolahan secara kimia seperti dengan presipitasi (pengendapan), adsorpsi (penyerapan), filtrasi (penyaringan) dan koagulasi. Pengolahan kimia yang biasa dilakukan yaitu melalui proses pengendapan dengan proses koagulasi-flokulasi dengan koagulan yang beragam. Koagulasi flokulasi merupakan metode yang efektif untuk pengolahan limbah industri yang mengandung logam berat, karena dengan metode ini akan terjadi pemisahan antara endapan dan beningan. Metode pengendapan dengan koagulasi dipilih karena dalam limbah elektroplating terdapat konstituen kimia seperti kation-kation yang dapat diubah menjadi bentuk senyawa tak larut dengan menambahkan bahan pengendap (Sugeng, 2010). Pada metode ini biasanya digunakan suatu koagulan sintetik. Koagulan yang umumnya dipakai adalah kapur (Matra dan Zainus, 2011), garam-garam aluminium seperti aluminium sulfat (Eva dan Andri, 2009), garam-garam besi seperti ferri sulfat (Prayitno et al., 1998) dan PAC (polyaluminium chloride) (Patimah dan Daur L, 2009).

Tujuan penelitian ini adalah mengetahui massa koagulan, $\mathrm{pH}$ dan massa KI optimal yang digunakan pada proses koagulasi- flokulasi dalam menurunkan kandungan logam berat pada limbah elektroplating. Koagulan yang digunakan pada penelitian ini yaitu koagulan ferri klorida. Ferri klorida digunakan karena sifatnya yang akan mengion menjadi kation. Kation ini nantinya akan bereaksi dengan ion hidroksida dan mengendap menjadi padatan hidroksida logam yang tidak larut dan akan menarik kation logam yang berada dalam limbah sehingga koagulan ini efektif untuk menurunkan kadar logam berat yang terdapat pada limbah elektroplating. Selain itu koagulan ferri klorida akan membentuk flok yang lebih berat, sehingga lebih cepat mengendap (Praswasti et al., 2010).

\section{METODE PENELITIAN}

\section{Waktu dan Tempat Penelitian}

Penelitian dilakukan di Laboratorium Pusat Teknologi Limbah Radioaktif (PTLR)BATAN pada bulan Februari - Juni 2012., yang beralamat di Jalan Raya Puspitek Gedung 50, Serpong, Tangerang 15310 Banten.

\section{Alat dan Bahan}

Peralatan yang digunakan dalam penelitian ini diantaranya adalah Jar Test (Velp Scientifica JLT6 Leaching Test Jartest), Portable pH meter (Mettler Toledo), Neraca Analitik (Mettler Toledo), Labu takar (Iwaki Pyrex), Stopwatch, Spektrofotometer Serapan atom (SSA) (Analyst 400 Perkin Elmer) dan peralatan gelas lainnya.

Bahan-bahan yang digunakan terdiri dari $\mathrm{K}_{2} \mathrm{CrO}_{4}, \quad \mathrm{Cr}\left(\mathrm{NO}_{3}\right)_{3 . .} 9 \mathrm{H}_{2} \mathrm{O}, \quad \mathrm{FeCl}_{3} \cdot 6 \mathrm{H}_{2} \mathrm{O}$, $\mathrm{CuCl}_{2} \cdot 2 \mathrm{H}_{2} \mathrm{O}, \quad \mathrm{MnCl}_{2}, \quad \mathrm{Ni}\left(\mathrm{NO}_{3}\right)_{2} \cdot 4 \mathrm{H}_{2} \mathrm{O}$, $\mathrm{Zn}\left(\mathrm{NO}_{3}\right)_{2} \cdot 4 \mathrm{H}_{2} \mathrm{O}, \mathrm{KI}, \mathrm{HCl}$ dan $\mathrm{NaOH}$.

\section{Pembuatan Limbah Simulasi}

Pembuatan limbah simulasi dilakukan dengan cara melarutkan masing-masing 0,6553 $\mathrm{g} \mathrm{K}_{2} \mathrm{CrO}_{4} ; 1,3501 \mathrm{~g} \mathrm{Cr}\left(\mathrm{NO}_{3}\right)_{3} .9 \mathrm{H}_{2} \mathrm{O} ; 0,1894 \mathrm{~g}$ $\mathrm{FeCl}_{3} \cdot 6 \mathrm{H}_{2} \mathrm{O} ; 0,2109 \mathrm{~g} \mathrm{CuCl}_{2} \cdot 2 \mathrm{H}_{2} \mathrm{O} ; 0,0599 \mathrm{~g}$ $\mathrm{MnCl}_{2} ; 0,0692 \mathrm{~g} \mathrm{Ni}\left(\mathrm{NO}_{3}\right)_{2} \cdot 4 \mathrm{H}_{2} \mathrm{O}$, dan $0,0834 \mathrm{~g}$ $\mathrm{Zn}\left(\mathrm{NO}_{3}\right)_{2} \cdot 4 \mathrm{H}_{2} \mathrm{O}$ kedalam 2 liter aquades, sehingga diperoleh limbah simulasi yang mengandung krom, besi, tembaga, mangan, nikel, dan seng dengan kadar berturut-turut 
87,$73 ; 87,73 ; 19,57 ; 39,31 ; 13,09 ; 6,98$ dan $10,43 \mathrm{mg} / \mathrm{L}$.

\section{Proses pengolahan limbah elektroplating}

$300 \mathrm{~mL}$ limbah cair yang telah diketahui kadar dan pHnya dimasukkan kedalam 6 buah gelas beker. Ditambahkan ferri klorida sebanyak 0,$034 ; 0,067 ; 0,135 ; 0,273 ; 0,555$ dan 1,092 g. Diatur pHnya 5, 6, 7, 8, 10 dan 11 kemudian diaduk dengan kecepatan $125 \mathrm{rpm}$ selama 5 menit dan dilanjutkan dengan pengadukan dengan kecepatan $45 \mathrm{rpm}$ selama 15 menit. Campuran didiamkan sampai terpisah sempurna selama 1 jam. Dilakukan analisis kadar logam dalam beningan dengan menggunakan SSA.

\section{Penentuan massa optimal KI}

Dalam uji penentuan massa KI optimum ini bertujuan untuk mereduksi krom (VI) menjadi krom (III). Penentuan massa reduktor KI ini dilakukan dengan metode Jar test. Dicampurkan 0,$1 ; 0,2 ; 0,3 ; 0,4 ; 0,5$ dan $0,7 \mathrm{~g}$ padatan KI dengan $300 \mathrm{~mL}$ limbah cair elektroplating yang memiliki $\mathrm{pH} 2$, kemudian ditambahkan $\mathrm{FeCl}_{3}$ sebanyak 1,092 $\mathrm{g}$ dan $\mathrm{NaOH} 1 \mathrm{~N}$ sampai pH 5. Kemudian pada beningan dilakukan analisis $\mathrm{pH}$ dan kadar krom. Kadar krom yang paling kecil menunjukkan dosis penggunaan reduktor $\mathrm{KI}$ yang optimal.

\section{HASIL DAN PEMBAHASAN}

\section{Proses Pengolahan Limbah Elektroplating}

Proses pengolahan limbah elektroplating menggunakan ferri klorida prinsipnya berdasarkan pada reaksi pengendapan kation logam. Ferri klorida digunakan sebagai koagulan karena sifatnya yang akan mengion di dalam air menjadi kation $\mathrm{Fe}^{3+}$. Kation ini nantinya akan bereaksi dengan ion hidroksida dalam larutan menjadi padatan hidroksida logam yang tidak larut dalam air (Praswasti et al., 2010). Penentuan rasio massa optimum ferri klorida yang digunakan terhadap limbah dalam proses pengurangan kandungan logam berat pada limbah elektroplating dilakukan dengan metode jar test. Penentuan massa koagulan dilakukan dengan cara menghitung dosis koagulan melalui reaksi stoikiometri antara koagulan dan logam, kemudian dilakukan pengaturan $\mathrm{pH}$.

\section{Proses pengolahan logam besi}

Logam Fe digunakan sebagai alloy dengan logam krom untuk meningkatkan daya tahan dan mampu mencegah korosi pada pelapisan stainless steel (Widowati et al., 2008). Limbah hasil pencemaran logam Fe dapat memberikan efek dalam paru-paru. Tabel 1 menunjukkan penurunan kadar logam $\mathrm{Fe}$ dalam limbah pada rasio massa koagulan dan limbah sebesar 0,$11 ; 0,22 ; 0,45 ; 0,91 ; 1,85$ dan 3,64 dengan variasi $\mathrm{pH} 5,6,7,8,10$ dan 11 . Hasil proses koagulasi dengan koagulan ini untuk logam $\mathrm{Fe}$ menunjukkan bahwa kadar logam Fe dalam beningan tidak terdeteksi untuk seluruh variabel operasi.

\section{Proses pengolahan logam krom}

Krom pada industri elektroplating digunakan pada proses lapis keras dengan tujuan sebagai anti kusam (BAPEDAL, 1996). Efek toksik logam $\mathrm{Cr}$ hasil limbah industri elektroplating dapat bersifat bioakumulatif dan tidak dapat terurai. Penurunan kadar $\mathrm{Cr}$ dalam limbah dapat dilihat pada Gambar 1.

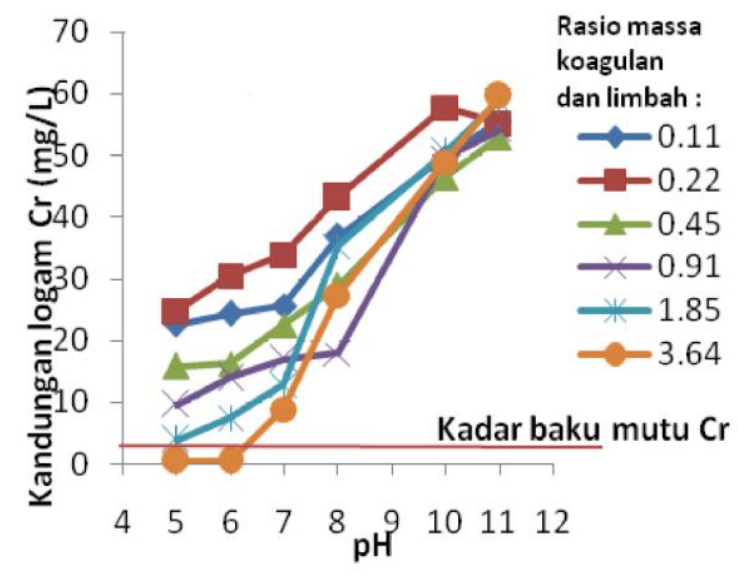

Gambar 1. Pengaruh $\mathrm{pH}$ terhadap penyisihan kadar logam krom 
Berdasarkan Gambar 1, pH optimum yaitu $\mathrm{pH} 5$ pada rasio massa koagulan dan limbah sebesar 3,64 yang memberikan penurunan rata-rata sebesar $99 \%$. Massa koagulan yang semakin banyak maka endapan $\mathrm{Cr}(\mathrm{OH})_{3}$ semakin mudah terbentuk dan kadar logam $\mathrm{Cr}$ semakin menurun. Krom pada limbah akan berinteraksi dengan ion $\mathrm{OH}^{-}$yang menyebabkan $\mathrm{Cr}$ akan mengendap dalam limbah membentuk $\mathrm{Cr}(\mathrm{OH})_{3}$. Endapan $\mathrm{Cr}(\mathrm{OH})_{3}$ dapat berperan sebagai inti flok yang bersifat elektropositif dan akan menarik kelebihan $\mathrm{OH}^{-}$ didalam larutan sehingga membentuk flok $\mathrm{Cr}(\mathrm{OH})_{4}{ }^{-}$dan dapat menarik kation logam lainnya yang terdapat dalam limbah (Praswasti et al., 2010). Persentase penyisihan logam $\mathrm{Cr}$ terbesar yaitu 99,52\% atau kadar $\mathrm{Cr} 0,43$ $\mathrm{mg} / \mathrm{L}$. Pada rasio massa sebesar 3,64 hasil analisis menunjukkan kandungan logam $\mathrm{Cr}$ pada limbah telah memenuhi baku mutunya, sedangkan pada limbah terdapat ion krom (VI) yang tidak dapat diendapkan secara langsung tanpa proses reduksi dengan KI, hal ini dapat diakibatkan karena terjadinya proses kopresipitasi ion krom (VI) pada limbah, sehingga ion krom (VI) ikut serta tertarik oleh flok $\mathrm{Cr}(\mathrm{OH})_{4}{ }^{-}$dan mengendap. Proses kopresipitasi ini terjadi karena adsorpsi partikel asing pada permukaan endapan yang sedang terbentuk (Underwood, 2002). Berdasarkan baku mutu air limbah pada Keputusan Menteri Lingkungan Hidup No 15 tahun 1995, kandungan krom total pada hasil pengolahan telah memenuhi baku mutu yang ditetapkan pemerintah yaitu sebesar $0,5 \mathrm{mg} / \mathrm{L}$.

\section{Proses pengolahan logam seng}

Pelapisan logam dengan $\mathrm{Zn}$ merupakan salah satu proses pelapisan logam yang paling banyak dalam industri. Tujuan pelapisan ini agar lebih tahan korosi dan sebagai lapis dasar sebelum proses kromatisasi (BAPEDAL, 1996).

Pada Gambar 2 nilai $\mathrm{pH}$ yang semakin besar menyebabkan kadar $\mathrm{Zn}$ semakin menurun, yang kadarnya mulai menunjukkan nilai berasimtot (membentuk garis lurus) pada $\mathrm{pH} 8$.
Rasio massa koagulan dan limbah yang semakin besar juga menyebabkan terbentuknya endapan $\mathrm{Fe}(\mathrm{OH})_{3}$ dan flok $\mathrm{Fe}(\mathrm{OH})_{4}{ }^{-}$semakin mudah terjadi dan selanjutnya akan menarik kation Zn. Semakin banyak massa koagulan yang ditambahkan maka semakin tinggi nilai pH, (Vogel, 1985). Untuk logam Zn sesuai Gambar 2 didapatkan persentase penyisihan terbesar yaitu 94,45\% atau kadar Zn sebesar $0,58 \mathrm{mg} / \mathrm{L}$ pada rasio massa koagulan dan limbah 0,11. Logam $\mathrm{Zn}$ telah memenuhi baku mutunya. Menurut Keputusan Menteri Lingkungan Hidup No 51 Tahun 1995 tentang Baku Mutu Limbah Cair bagi kegiatan Industri, nilai baku mutunya tersebut sebesar $5 \mathrm{mg} / \mathrm{L}$.

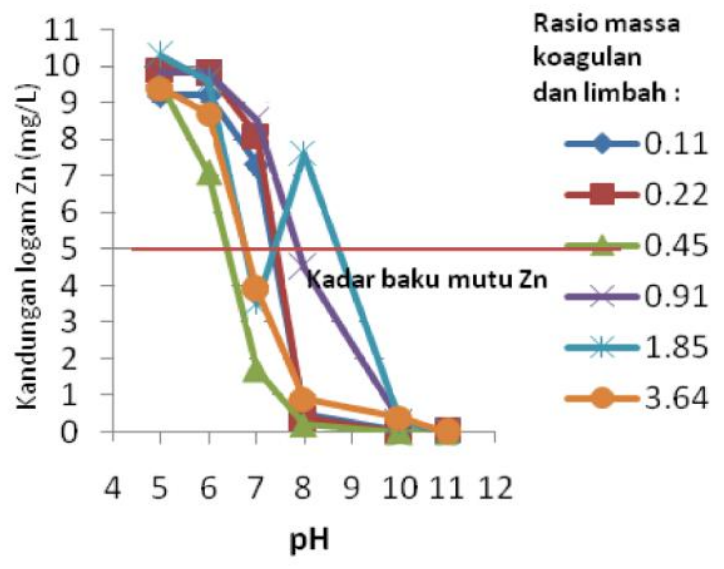

Gambar 2. Pengaruh $\mathrm{pH}$ terhadap penyisihan kadar logam seng

\section{Proses pengolahan logam tembaga}

Tembaga pada industri elektroplating digunakan untuk membuat lapisan dasar sebelum pelapisan logam berikutnya dan sebagai lapisan pelindung (BAPEDAL, 1996). Limbah yang mengandung tembaga tidak dapat diuraikan di alam, sehingga akan terakumulasi di dalam tanaman dan tumbuhan. Efek toksik tembaga dapat menimbulkan kerusakan pada hati, otak dan ginjal (Widowati et al., 2008).

Pada Tabel 1, nilai $\mathrm{pH}$ optimum pada pH 5, karena pada $\mathrm{pH}$ ini kadar logam $\mathrm{Cu}$ mengalami penurunan yang signifikan. Semakin tinggi $\mathrm{pH}$, semakin besar persentase penurunan logam $\mathrm{Cu}$ pada limbah, Sedangkan rasio massa koagulan dan limbah yang optimum terdapat pada rasio massa sebesar 
Tabel 1. Hasil analisis logam tembaga

\begin{tabular}{|c|c|c|c|c|c|c|c|c|c|c|c|c|c|c|}
\hline \multirow[t]{2}{*}{$\mathrm{pH}$} & \multirow{2}{*}{$\begin{array}{c}\mathrm{M}_{0} \\
(\mathrm{mg} / \mathrm{L})\end{array}$} & \multicolumn{12}{|c|}{$\mathrm{M}_{1}(\mathrm{mg} / \mathrm{L}), \%$} & \multirow{2}{*}{$\begin{array}{c}\text { Baku } \\
\text { mutu } \\
(\mathrm{mg} / \mathrm{L})\end{array}$} \\
\hline & & \multicolumn{2}{|c|}{ Rasio 0,11} & \multicolumn{2}{|c|}{ Rasio 0,22} & \multicolumn{2}{|c|}{ Rasio 0,45} & \multicolumn{2}{|c|}{ Rasio 0,91} & \multicolumn{2}{|c|}{ Rasio1,85 } & \multicolumn{2}{|c|}{ Rasio 3,64 } & \\
\hline 5 & 39,31 & 0,92 & 97,66 & $\operatorname{ttd}$ & - & $\mathrm{ttd}$ & - & $\mathrm{ttd}$ & - & & & & & \\
\hline 6 & 39,31 & $\operatorname{ttd}$ & - & $\mathrm{ttd}$ & - & $\mathrm{ttd}$ & - & $\mathrm{ttd}$ & - & & & & & \\
\hline 7 & 39,31 & ttd & - & $\operatorname{ttd}$ & - & $\mathrm{ttd}$ & - & $\mathrm{ttd}$ & - & $\mathrm{ttd}$ & - & $\mathrm{ttd}$ & - & 2 \\
\hline 8 & 39,31 & $\operatorname{ttd}$ & - & $\operatorname{ttd}$ & - & 0,34 & 99,14 & 2,66 & 93,23 & & & & & \\
\hline 10 & 39,31 & 2,32 & 94,09 & 0,68 & 98,27 & 0,04 & 99,89 & Ttd & - & & & & & \\
\hline 11 & 39,31 & $\operatorname{ttd}$ & - & Ttd & - & $\operatorname{ttd}$ & - & Ttd & - & & & & & \\
\hline
\end{tabular}

Keterangan : $\mathrm{M}_{0}=$ Kadar limbah awal, $\mathrm{M}_{1}=$ kadar limbah akhir, $\%=$ persentase penyisihan,

Rasio $=$ rasio massa koagulan dan limbah

0,11 dengan persentase penyisihan $97,65 \%$ atau kadar $\mathrm{Cu}$ sebesar $0,92 \mathrm{mg} / \mathrm{L}$, karena pada rasio massa 0,11 kadar $\mathrm{Cu}$ dalam limbah sudah memenuhi baku mutunya. Baku mutu logam $\mathrm{Cu}$ dalam Keputusan Menteri Lingkungan Hidup No 51 tahun 1995 yaitu sebesar 2 mg/L.

\section{Proses pengolahan logam nikel}

Selain menurunkan kadar logam seng dan tembaga, koagulan ferri klorida juga digunakan untuk menurunkan kadar logam nikel. Nikel pada industri elektroplating digunakan pada lapisan bawah untuk pelapisan dekoratif krom yang melapisi komponen baja (BAPEDAL, 1996).

Pada Gambar 3, nilai pH yang semakin besar menyebabkan kadar $\mathrm{Ni}$ semakin menurun, yang kadarnya mulai menunjukkan nilai berasimtot pada $\mathrm{pH}$ 7. Pada $\mathrm{pH} 7$ ini kadar logam Ni pada beningan mengalami penurunan yang signifikan.

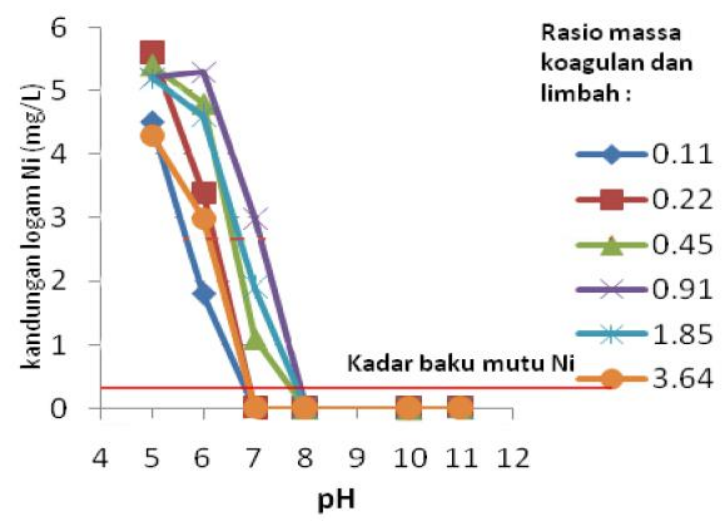

Gambar 3. Pengaruh $\mathrm{pH}$ terhadap penyisihan kadar logam nikel
Rasio massa koagulan dan limbah yang semakin banyak menyebabkan terbentuknya endapan $\mathrm{Fe}(\mathrm{OH})_{3}$ dan flok $\mathrm{Fe}(\mathrm{OH})_{4}{ }_{4}^{-}$. Semakin banyak massa koagulan yang ditambahkan dan semakin tinggi nilai $\mathrm{pH}$, akan menyebabkan semakin banyak ion $\mathrm{OH}^{-}$yang akan bereaksi dengan logam Ni untuk membentuk endapan $\mathrm{Ni}(\mathrm{OH})_{2}$ pada limbah (Vogel, 1985). Kadar nikel pada harga optimum terdapat pada rasio massa sebesar 0,11. Pada kadar ini telah memenuhi nilai baku mutunya. Baku mutu Ni menurut Keputusan Menteri Lingkungan Hidup No 51 Tahun 1995 tentang Baku Mutu Limbah Cair bagi kegiatan industri yaitu sebesar $0,2 \mathrm{mg} / \mathrm{L}$.

\section{Proses pengolahan logam mangan}

Mangan pada industri elektroplating digunakan sebagai logam pelapis untuk stainless steel dengan komposisi sebesar 2\% (Widowati et al., 2008). Penggunaan koagulan ferri klorida dapat menurunkan kadar logam Mn dalam limbah. Reaksi yang terjadi pada penurunan kadar $\mathrm{Mn}$ seperti pada reaksi $\mathrm{Zn}, \mathrm{Cu}$ dan Ni. Pada Gambar 4, penurunan kadar logam Mn meningkat dengan meningkatnya nilai $\mathrm{pH}$ dan semakin besar rasio massa koagulan dengan limbah, semakin besar pula penurunan kadar Mn dalam larutan, hal ini dikarenakan semakin banyak koagulan yang bereaksi membentuk endapan $\mathrm{Fe}(\mathrm{OH})_{3}$ (Praswasti et al., 2010; Reynolds, 1982).

Penurunan kadar Mn optimum terdapat pada rasio massa koagulan dan limbah sebesar 0,45 . Pada rasio ini kadar Mn yaitu sebesar 
1,02 $\mathrm{mg} / \mathrm{L}$ atau dengan persentase penyisihan $92,18 \%$, pada kadar ini logam Mn telah memenuhi baku mutunya. Baku mutu logam Mn menurut Keputusan Menteri Lingkungan Hidup No 51 Tahun 1995 tentang Baku Mutu Limbah Cair bagi kegiatan industri yaitu sebesar $2 \mathrm{mg} / \mathrm{L}$.

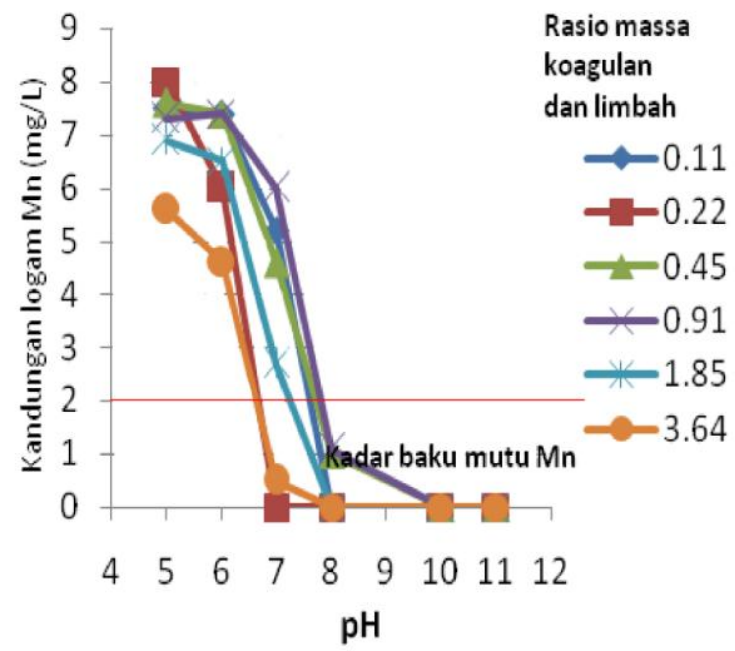

Gambar 4. Pengaruh $\mathrm{pH}$ terhadap penyisihan kadar logam mangan

Tipe endapan yang dihasilkan pada proses koagulasi dan flokulasi adalah endapan jenis Gelatinous. Pada jenis ini, endapan yang terbentuk memiliki ukuran yang lebih besar, lebih berdekatan dengan warna endapan kecoklatan. Ferri klorida merupakan suatu koagulan yang berkerja pada $\mathrm{pH}$ optimal antara pH 5 sampai dengan $\mathrm{pH} 12$ (Eckenfelder, 2000). Pada percobaan didapatkan $\mathrm{pH}$ optimal untuk setiap logam berbeda, yaitu untuk logam $\mathrm{Zn}, \mathrm{Fe}, \mathrm{Ni}$, dan $\mathrm{Mn}$ pada $\mathrm{pH} 7$ sedangkan untuk $\mathrm{Cr}$ dan $\mathrm{Cu}$ pada $\mathrm{pH} 5$ dengan rasio massa koagulan dan limbah optimal berbeda untuk setiap logamnya. Untuk penerapan dalam pengolahan limbah elektroplating secara keseluruhan, digunakan rasio massa ferri klorida dan limbah yang menunjukkan kadar setiap logamnya yang memenuhi standar baku mutu untuk setiap logam berat berdasarkan KEPMEN LH No 51 Tahun 1995.

\section{Penentuan massa KI (Kalium Iodida)}

Kalium iodida digunakan sebagai reduktor untuk mereduksi $\mathrm{Cr}^{6+}$ yang terkandung didalam limbah elektroplating. Pada proses ini ion $\mathrm{Cr}^{6+}$ direduksi menjadi $\mathrm{Cr}^{3+}$. Proses ini dilakukan karena $\mathrm{Cr}^{6+}$ tidak dapat diendapkan secara langsung menggunakan ferri klorida (Zainus dan Matra, 2011). Proses penambahan KI ini dilakukan variasi massa dengan tujuan untuk mengetahui massa optimal penggunaan KI. Proses reduksi dilakukan pada $\mathrm{pH} 2$, karena reaksi reduksi akan berjalan sempurna pada $\mathrm{pH}$ asam. Gambar 5 adalah grafik penurunan kadar krom pada limbah elektroplating dengan variasi penambahan reduktor KI.

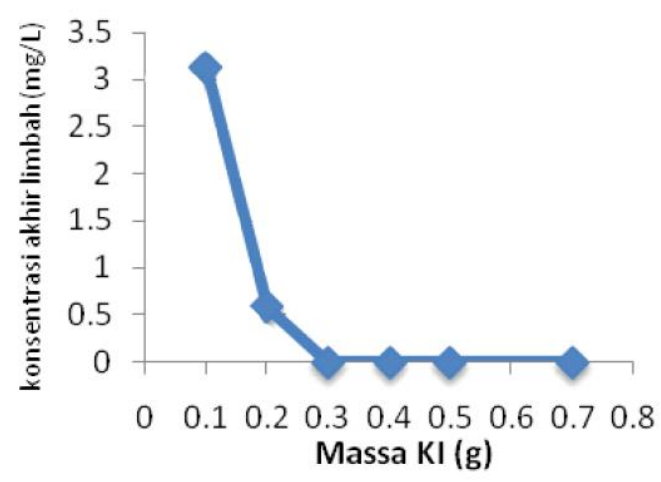

Gambar 5. Pengaruh penambahan massa reduktor $\mathrm{KI}$ dan $1 \mathrm{~g} \mathrm{FeCl}_{3}$ terhadap penyisihan kandungan krom pada $300 \mathrm{~mL}$ limbah.

Berdasarkan Gambar 5, massa reduktor KI yang paling optimum adalah $0,3 \mathrm{~g}$ dalam $300 \mathrm{~mL}$ limbah elektroplating atau rasio massa dan limbah sebesar 1. Harga optimum persentase penyisihan krom terbesar pada $0,3 \mathrm{~g}$ yang memberikan penurunan persentase penyisihan krom dalam limbah sampai pada baku mutunya. Hal ini terlihat pada Gambar 5 dimana setelah penambahan KI lebih besar dari $0,3 \mathrm{~g}$, persentase penyisihan kadar krom tetap.

Hasil optimal pengendapan krom tanpa reduksi didapatkan penurunan kadar limbah sebesar 78,75 mg/L atau kadar Cr sebesar 8,98 $\mathrm{mg} / \mathrm{L}$ dan untuk pengendapan krom dengan reduksi menggunakan $0,3 \mathrm{~g}$ KI didapatkan penurunan sebesar $87,73 \mathrm{mg} / \mathrm{L}$ atau kadar $\mathrm{Cr}$ dalam beningan sebesar $\leq 0$. 


\section{KESIMPULAN}

Kesimpulan

Berdasarkan penelitian yang telah dilakukan, diperoleh kesimpulan sebagai berikut :

1. $\mathrm{pH}$ optimal untuk logam $\mathrm{Zn}, \mathrm{Fe}, \mathrm{Ni}$, dan $\mathrm{Mn}$ adalah pada $\mathrm{pH} 7$ sedangkan untuk $\mathrm{Cr}$ dan $\mathrm{Cu}$ pada $\mathrm{pH} 5$.

2. Massa reduktor KI optimal untuk mereduksi krom (VI) menjadi krom (III) dilanjutkan proses koagulasi-flokulasi yaitu $0,3 \mathrm{~g}$.

3. Penurunan optimal kadar $\mathrm{Cr}$ tanpa reduksi sebesar 87,32 $\mathrm{mg} / \mathrm{L}$ sedangkan dengan proses reduksi sebesar $83,36 \mathrm{mg} / \mathrm{L}$.

4. Penggunaan koagulan ferri klorida pada pengolahan limbah industri elektroplating dapat menurunkan kadar logam berat sampai pada nilai baku mutunya

\section{Saran}

Melakukan variasi terhadap proses pengadukan serta variasi lamanya pengendapan dan melakukan koagulasi bertingkat untuk koagulan yang digunakan.

\section{UCAPAN TERIMAKASIH}

Pada kesempatan ini penulis mengucapkan terima kasih kepada Bapak Prof. Ir. Zainus Salimin, M.Si dan Ita Nurifitriyani yang telah memberi izin untuk mempublikasikan penelitian ini.

\section{Daftar Pustaka}

Badan Pengelola Dampak Lingkungan. 1996. Teknologi Pengendalian Dampak Lingkungan Industri Lapis Listrik. Jakarta : Kementrian Negara Lingkungan Hidup.

Eckenfelder. 2000. Industrial Water Pollution Control, Third Edition, New York : Mc. Graw Hill Book Company.

Keputusan Menteri Lingkungan Hidup Nomor 51 Tahun 1995 Tentang Baku Mutu Limbah Cair Bagi Kegiatan Industri. Jakarta : Kementrian Negara Lingkungan Hidup.

Palar, H. 1994. Pencemaran dan Toksikologi Logam Berat. Jakarta : Rineka Cipta.

Patimah, dan Lumban R S. 2009. Pengaruh Penambahan Polyaluminium Chloride (PAC)
Terhadap Nilai Turbinitas Air Sebagai Bahan Baku Produk Minuman di PT. CocaCola Indonesia Bottling Medan. Skripsi. Medan : Universitas Sumatra Utara.

Peraturan Pemerintah Republik Indonesia Nomor 18 tahun 1999 Jo. Peraturan Pemerintah Nomor 85 Tahun 1999 Tentang Pengelolaan Limbah Bahan Berbahaya dan Beracun.

Peraturan Pemerintah Republik Indonesia Nomor 82 Tahun 2001 Tentang Pengelolaan Kualitas Air dan Pengendalian Pencemaran Air.

Praswasti PDK, Dianursanti, Misri Gozan, dan Wahyu Ardie Nugroho. 2010. Optimasi Penggunaan Koagulan Pada Pengolahan Air Limbah Batubara. Prosiding Seminar Nasional Teknik Kimia "Kejuangan" Pengembangan Teknologi Kimia untuk Pengolahan Sumber Daya Alam Indonesia. Jakarta : Universitas Indonesia.

Prayitno, R, M.E Budiyono dan Puji Lestari. 1998. Penurunan Kadar Uranium Dalam Fasa Air Dengan Proses Koagulasi Flokulasi Dengan Garam Ferri. Prosiding Presentasi Ilmiah Daur Bahan Bakar Nuklir IV. Jakarta : BATAN- PEBN

Purwanto, dan Syamsul H. 2005,.Teknologi Industri Elektroplating. Semarang : Universitas Diponegoro.

Reynolds, T.D. 1982. Unit Operations and Processes In Environmental Engineering. California : Texas University.

Roekmijati. 2002. Presipitasi Bertahap Logam Berat Limbah Cair Industri Pelapisan Logam Menggunakan Larutan Kaustik Soda. Jurnal kimia lingkungan. Jakarta : Universitas Indonesia.

Salimin Z, Gunandjar, Deddy H, Hendro, dan Sugeng P. 2000. Proses Kimia Pengolahan Limbah Cair Telurium dan Krom dari Produksi Radioisotop I-131. Prosiding Seminar Nasional Pengelolaan Limbah. Jakarta : BATAN-PTLR.

Underwood A. L. and Day R. A. J.R, 2002. Analisis Kimia Kuantitatif Edisi keenam, Erlangga, Jakarta.

Vogel. 1985. Analisis Anorganik Kualitatif Makro dan Semi Makro, Edisi 5 . PT.Kalman Media Pustaka, Jakarta.

Widowati W, Astiana S, dan Raymond J. 2008. Efek Toksik Logam. Bandung : ANDI Yogyakarta. 
Valensi Vol. 3 No. 1, Mei 2013 (41-47)

ISSN : 1978 - 8193 